\title{
FLUORIDE RELEASE OF SIX RESTORATIVE MATERIALS IN WATER AND pH-CYCLING SOLUTIONS
}

\author{
Rosa Maria Viana de Bragança GARCEZ1, Marília Afonso Rabelo BUZALAF², Paulo Amarante de ARAÚJO
}

1- DDs, MSc, Graduate student (Doctor Degree), Department of Dentistry, Endodontic and Dental Materials, Bauru Dental School, University of São Paulo, Bauru, Brazil. Assistant Professor of the Department of Dentistry, Health and Biological Science Center, Federal University of Sergipe, Brazil.

2- DDS, MSc, PhD, Associate Professor, Department of Biological Sciences, Bauru Dental School, University of São Paulo, Bauru, Brazil. 3- DDS, MSc, PhD, Associate Professor, Department of Operative Dentistry, Endodontics and Dental Materials, Bauru Dental School, University of São Paulo, Bauru, Brazil.

Corresponding address: Rosa Maria Viana de Bragança Garcez - Rua Frei Paulo, 344 - Bairro Suíça - Aracaju - $49.052-270$ - SE - Brasil Phone: 5579 3221-1106/55 79 2105-1821 - Fax: 5579 2105-1823 - e-mail: rgarcez@ufs.br

Received: August 24, 2006 - Modification: October 16, 2006 - Accepted: July 10, 2007

\begin{abstract}
7

he fluoride release of restorative materials in deionized water has been the subject of many studies, but the behavior of these materials under conditions of acid challenge that simulates the oral cavity, needs to be further explored. Therefore, the aim of this study was to evaluate the fluoride release of restorative materials in two storage protocols: deionized water and $\mathrm{pH}$ cycling system (demineralizing solution-pH 4.3 and remineralizing solution-pH 7.0) for 15 days. Eight disks of each material (Vitremer ${ }^{\mathrm{TM}}$-positive control, Dyract AP, Ariston pHc, Definite ${ }^{\circledR}$, Tetric ${ }^{\circledR}$ Ceram and Z100-negative control) were prepared (11.0 $\mathrm{mm} \times 1.5 \mathrm{~mm}$ ) and suspended individually in $4.0 \mathrm{~mL}$ of each solution, which were daily changed. Daily fluoride release was analyzed with an ion specific electrode (Orion 9609) by the direct method or after HMDS-facilitated diffusion, following 1, 7 and 15 days. The values obtained were converted into $\mu \mathrm{gF} / \mathrm{mm}^{2}$ and the data analyzed by ANOVA and Tukey's test ( $\mathrm{p}<0.05$ ). The results showed that all materials released more fluoride in the $\mathrm{pH}$-cycling system, except for Ariston $\mathrm{pHc}$ which maintained a constant release during the experiment. The highest fluoride release was presented by the positive control, Vitremer ${ }^{\mathrm{TM}}$ in $\mathrm{pH}-$ cycling and by Ariston pHc, in deionized water. The negative control Z100 and the resins Definite ${ }^{\circledR}$ and Tetric ${ }^{\circledR}$ Ceram did not present statistically significant differences.
\end{abstract}

Uniterms: Fluoride release; pH-cycling; Glass ionomer cements; Composite resins.

\section{INTRODUCTION}

The widespread use of fluoride has contributed to improve the remineralization of the enamel and dentin exposed to acid challenge in the oral environment ${ }^{20}$.

Fluoride has been added to community water supply, gels and solutions for topical applications, toothpastes, mouthwash solutions and pit-and-fissures sealants, which have been established as preventive caries methods for a long time ${ }^{2}$.

In the last two decades, the addition of fluoride to restorative materials has attracted the attention of dental researchers and clinicians as for the possibility of using these materials as a source of low fluoride release to the teeth, within long periods. These so-called "intelligent" dental materials have been elaborated with the purpose of reducing secondary caries and neutralizing the $\mathrm{pH}$ decrease, especially in high-caries risk patients. Their mechanical and esthetic properties have been improved and most of them can now be used to restore posterior teeth. As most works in the literature report results of fluoride release from dental materials based upon measurements in deionized water and artificial saliva ${ }^{8}$, fluoride release from different restorative materials, using a medium that could better simulate the caries process, using a $\mathrm{pH}$-cycling system ${ }^{14}$ with demineralizing and remineralizing solutions, over 15 days, was determined.

\section{MATERIALAND METHODS}

Table 1 shows the materials used in the present study. A sample of six specimens for each experimental condition was established. The negative control group was represented by $Z 100(Z)$ and the positive one by Vitremer ${ }^{\mathrm{TM}}(\mathrm{V})$. Dyract AP (DY), Tetric ${ }^{\circledR}$ Ceram (TC), Ariston $\mathrm{pHc}(\mathrm{A})$ and Definite ${ }^{\circledR}$ (D) were considered the experimental group. Therefore, 16 specimens of each material were prepared as thin disks (11 mm diameter; $1.5 \mathrm{~mm}$ thickness), using a Teflon mold. All materials were prepared according 
to the manufacturers' recommendations at room temperature $\left(23^{\circ} \pm 1^{\circ} \mathrm{C}\right)$ and controlled relative humidity $(50 \pm 5 \%)$, according to ISO specification \#7489. Each material was inserted into the Teflon molds, previously prepared with a dental floss piece, introduced in a central hole to suspend the specimens in the test medium, and pressed between two polyester strips by a microscopic glass slide on top of the materials. Vitremer ${ }^{\mathrm{TM}}$ and Dyract were inserted into the mold, using a Centrix syringe. The materials were individually lightcured for 40 seconds with an Optilux light activator (Demetron Research Corp., Danbury, CT, USA). The light intensity was controlled at $500 \mathrm{mV} / \mathrm{cm}^{2}$ by measuring with a curing radiometer. Ten minutes after curing, the specimens were removed from the Teflon molds and fixed individually on the caps of polyethylene tubes containing $4.0 \mathrm{~mL}$ of the studied solutions and stirred in an orbital shaker (Nova Técnica, NT 145), at room temperature $\left(24^{\circ} \pm 1^{\circ} \mathrm{C}\right)$, for 15 days. During this period, the specimens were periodically transferred to new experimental solutions. In deionized water, every 24 hours and, in the $\mathrm{pH}$-cycling system, the specimens were immersed for 6 hours in a demineralizing solution (calcium $2.0 \mathrm{mmol} \mathrm{L}^{-1}$, phosphate $2.0 \mathrm{mmol} \mathrm{L}^{-1}$ and acetate buffer $75 \mathrm{mmol} \mathrm{L}^{-1} \mathrm{pH} 4.3$ ) and for 18 hours, in a remineralizing solution (calcium $1.5 \mathrm{mmol} \mathrm{L}^{-1}$, phosphate $0.9 \mathrm{mmol} \mathrm{L}^{-1}$, potassium chloride $150 \mathrm{mmol} \mathrm{L}^{-1}$ and Tris buffer $20 \mathrm{mmol} \mathrm{L}^{-}$ ${ }^{1} \mathrm{pH} 7.0$ ), to simulate a situation of high caries challenge ${ }^{14}$. After the prescribed immersion time, the disks were removed from the solutions, dried with an absorbent paper and then transferred to new solutions. Each immersion solution was kept at $4^{\circ} \mathrm{C}$ until the measurements were performed.

\section{Fluoride Analyses}

The fluoride ion concentration in the solutions was measured using an Orion fluoride-specific electrode (model 96-09) and a Procyon digital ion-analyzer (model SA-720). For the analysis of fluoride, the same volumes of the solutions and TISAB II were mixed. The fluoride electrode was previously calibrated with a series of standard solutions ( 0.025 to $3.2 \mu \mathrm{gF} / \mathrm{mL}$ for deionized water and 0.1 to $6.4 \mu \mathrm{gF} /$ $\mathrm{mL}$ for the $\mathrm{pH}$-cycling). The $\mathrm{mV}$ readings were transformed into $\mu \mathrm{gF} / \mathrm{mm}^{2}$ and the results found in the demineralizing and remineralizing solutions were added and represented the fluoride release over 24 hours. For Definite ${ }^{\circledR}$, Tetric ${ }^{\circledR}$ Ceram and Z100, the analysis on the first, seventh and fifteenth days was determined through the HMDSfacilitated diffusion by the Taves' method ${ }^{25}$. Briefly, the volume of the samples $(0.5 \mathrm{~mL})$ was adjusted to $3.0 \mathrm{~mL}$ of deionized water, and $0.1 \mathrm{~mL}$ of $1.65 \mathrm{~mol} / \mathrm{L} \mathrm{NaOH}$ was added to the central trap in the Petri dishes (Falcon, \#1007). One ml of $6 \mathrm{~mol} / \mathrm{L} \mathrm{HCl}$, saturated with hexamethyldisiloxane, was added to the samples before the dishes were sealed. The specimens were maintained under stirring in a circular shaker equipment, at room temperature $\left(24^{\circ} \pm 1^{\circ} \mathrm{C}\right)$, for 12 hours. Fluoride standards ( 0.025 to $3.2 \mu \mathrm{gF} / \mathrm{mL}$ ) were prepared in triplicate and diffused as aforementioned above. At the end of the diffusion period, the $\mathrm{NaOH}$ traps were removed and the specimens contained in the traps were dried at $60^{\circ} \mathrm{C}$ for 2 hours, and buffered with $0.4 \mathrm{~mL}$ of $0.66 \mathrm{~mol} / \mathrm{L}$ acetic acid, in the analysis tube (Falcon, \#2017), placed in shaker tubes, so as to dissolve the $\mathrm{NaOH}$ crystals. The fluoride ion concentration in the solutions was measured using the same apparatus, as in the direct method.

\section{Statistical Analysis}

The data were analyzed statisticall, by the 3-way ANOVA and Tukey's test $(\mathrm{p}<0.05)$.

\section{RESULTS}

There was statistically significant differences among the different medium, material and time $(\mathrm{p}<0.05)$. The means of fluoride release of the materials, in each medium were analyzed by the Tukey's multiple-comparison test in the $1^{\text {st }}$, $7^{\text {th }}$ and $15^{\text {th }}$ days. Vitremer ${ }^{\mathrm{TM}}$ presented the highest fluoride release on the first day, followed by Ariston. Although all materials presented the same release pattern, the means recorded for the materials were different (Table 2). The fluoride release peak was observed on the first day and on the second day, a sharp decline was seen, after which a plateau was shown from days 7 to 15 , for all materials (Figure 1 and 2). Ariston exhibited a stable behavior, with small variations throughout the experiment. DY $>\mathrm{D}>\mathrm{TC}$ released

TABLE 1- Restorative materials' type, batch and manufacturers

\begin{tabular}{|c|c|c|c|}
\hline Product & Type of material & Batch \# & Manufacturers \\
\hline Z $100(Z)$ & Microhybrid radiopaque resin to posterior teeth & $9 \mathrm{EG}$ & 3M Dental \\
\hline Vitremer ${ }^{\mathrm{TM}}(\mathrm{V})$ & Resin-modified glass ionomer & 20000516 & 3M Dental \\
\hline Dyract AP (DY) & Polyacid-modified composite resin & 9908000277 & Dentsply \\
\hline Tetric $^{\circledR}$ Ceram (TC) & Composite resin with fluoride release & B 37704 & Vivadent \\
\hline Ariston $\mathrm{pHc}(\mathrm{A})$ & Esthetic restorative material with fluoride release & AO 9633 & Vivadent \\
\hline Definite $^{\circledR}(D)$ & $\begin{array}{l}\text { Composite resin based on organic modified ceramic } \\
\text { with fluoride release }\end{array}$ & \# & Degussa \\
\hline
\end{tabular}

\# Material provided by the manufacturer in capsules without the batch. 
the smallest amounts of fluoride, regardless of the medium, either deionized water or the $\mathrm{pH}$-cycling solutions (Table 2). Z100 had no statistically significant difference $(p<0.05)$ in the amount of fluoride release as compared to D and TC.

\section{DISCUSSION}

In the oral environment, the free fluoride ion promotes the inhibition of demineralization and the enhancement of remineralization ${ }^{26}$ of the enamel, from different sources. These characteristics were initially observed in silicate cement restorations, following the conventional glass ionomer cements. However, glass ionomer materials have some disadvantages, such as short working time, long setting time, susceptibility to early moisture and salivary contamination, desiccation after setting, and loss of brightness. In order to overcome these limitations and to preserve fluoride release, two types of hybrid materials, i.e., glass ionomers and composite resins have been combined to conciliate the advantages of conventional glass ionomers and the esthetic properties of the composites into one material with better mechanical and biological properties. These materials are the resin-modified glass ionomers and

TABLE 2- Fluoride release means $\left(\mu \mathrm{g} / \mathrm{mm}^{2}\right)$ and standard deviation of the restorative materials in $\mathrm{H}_{2} \mathrm{O}(\mathrm{n}=8)$ and $\mathrm{CpH}(\mathrm{n}=8)$ on the $1^{\text {st }}, 7^{\text {th }}$ and $15^{\text {th }}$ days

\begin{tabular}{|c|c|c|c|c|c|c|c|}
\hline Medium & Material & $\begin{array}{c}1^{\text {st }} \\
\text { Mean }\end{array}$ & $\begin{array}{c}\text { Day } \\
\text { SD }\end{array}$ & $\begin{array}{c}7^{\text {th }} \\
\text { Mean }\end{array}$ & $\begin{array}{c}\text { Day } \\
\text { SD }\end{array}$ & $\begin{array}{r}15^{\text {th }} \\
\text { Mean }\end{array}$ & $\begin{array}{c}\text { Day } \\
\text { SD }\end{array}$ \\
\hline $\mathrm{H}_{2} \mathrm{O}$ & $A$ & 0.3000 (a) & 0.1170 & 0.2306 (a) & 0.0584 & 0.2430 (a) & 0.0339 \\
\hline $\mathrm{H}_{2} \mathrm{O}$ & V & 0.6868 (b) & 0.1384 & 0.0531 (b) & 0.0137 & 0.0371 (b) & 0.0057 \\
\hline $\mathrm{H}_{2} \mathrm{O}$ & DY & 0.0616 (c) & 0.0181 & 0.0097 (c) & 0.0044 & 0.0070 (c) & 0.0011 \\
\hline $\mathrm{H}_{2} \mathrm{O}$ & $\mathrm{D}$ & 0.0011 (c) & 0.0001 & 0.0006 (c) & 0.0001 & 0.0003 (c) & 0.0002 \\
\hline $\mathrm{H}_{2} \mathrm{O}$ & $\mathrm{TC}$ & 0.0071 (c) & 0.0031 & 0.0005 (c) & 0.0002 & 0.0005 (c) & 0.0004 \\
\hline $\mathrm{H}_{2} \mathrm{O}$ & Z & 0.0010 (c) & 0.0003 & 0.0005 (c) & 0.0001 & 0.0005 (c) & 0.0001 \\
\hline $\mathrm{CPH}$ & $A$ & 0.2972 (a) & 0.0705 & 0.1481 (a) & 0.0131 & 0.0805 (a) & 0.0139 \\
\hline $\mathrm{CPH}$ & V & $1.3212(b)$ & 0.3330 & 0.1364 (a) & 0.0291 & 0.0835 (a) & 0.0146 \\
\hline $\mathrm{CPH}$ & DY & 0.2384 (a) & 0.0254 & 0.0732 (b) & 0.0056 & 0.0429 (b) & 0.0035 \\
\hline $\mathrm{CPH}$ & $D$ & 0.0045 (c) & 0.0007 & 0.0007 (c) & 0.0002 & 0.0011 (c) & 0.0002 \\
\hline $\mathrm{CPH}$ & $\mathrm{TC}$ & 0.0276 (c) & 0.0216 & 0.0010 (c) & 0.0002 & 0.0011 (c) & 0.0001 \\
\hline $\mathrm{CPH}$ & $Z$ & 0.0043 (c) & 0.0258 & 0.0011 (c) & 0.0002 & 0.0013 (c) & 0.0001 \\
\hline
\end{tabular}

Materials with equal letters were not statistically significant.

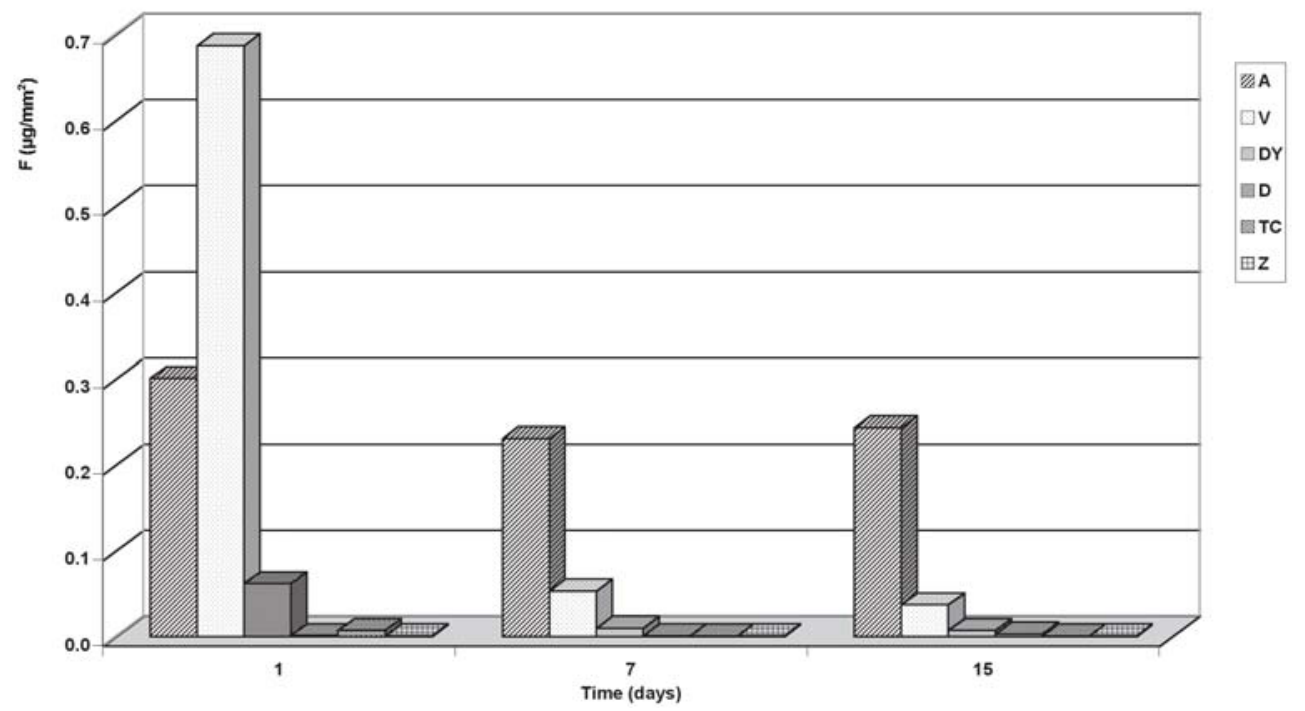

FIGURE 1- Fluoride release means $\left(\mu \mathrm{g} / \mathrm{mm}^{2}\right)$ of the restorative materials in $\mathrm{H}_{2} \mathrm{O}$, during 24 hours at the $1^{\text {st }}, 7^{\text {th }}$ and $15^{\text {th }}$ days 
the polyacid-modified composite resins, also known as "compomers", which have different setting mechanisms. The setting of the first material takes place through an acidbased reaction and polymerization and the compomers set solely by light polymerization with a limited acid-based reaction occurring later, as the material absorbs water from the oral environment. Owing to the consensus that fluoride release in low and constant concentrations is capable of reducing the level of demineralization and increasing remineralization of the adjacent dental enamel of restorations, thus preventing secondary $\operatorname{caries}^{10}$, manufacturers have incorporated fluoride to esthetic restorative materials. In the present study, the $\mathrm{pH}$-cycling regimen was used to reproduce the oral dynamic situation, first suggested by Featherstone, et al. ${ }^{14}$ (1986) and modified by Carvalho and Cury ${ }^{8}$ (1999), establishing a correlation with the development of in vivo caries, in high cariogenic challenges. According to Ten $\mathrm{Cate}^{26}$ (1990), this laboratorial model better simulates the variations of the $\mathrm{pH}$ in the oral environment.

Our findings suggest that the elution of fluoride occurs by two different processes, as previously reported by Vieira, et al. ${ }^{28}$. The first one is characterized by an initial burst of fluoride release from the surface. This process is accompanied by the second diffusion, in which small amounts of fluoride continue to be released into the

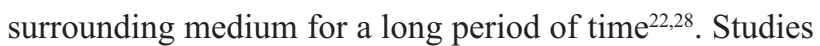
with deionized water measured the fluoride release in the medium without the presence of ionic force of various other elements present in the salivary fluid ${ }^{21}$. The pattern of fluoride release of the evaluated materials in deionized water and the $\mathrm{pH}$-cycling are consistent with those reported by Araújo, et al. ${ }^{3}$ (1996); Suljak and Hatibovic-Kofman²4(1996); Friedl, et al. ${ }^{16}(1997)$; Verbeeck, et al. ${ }^{27}(1998)$; Carvalho and

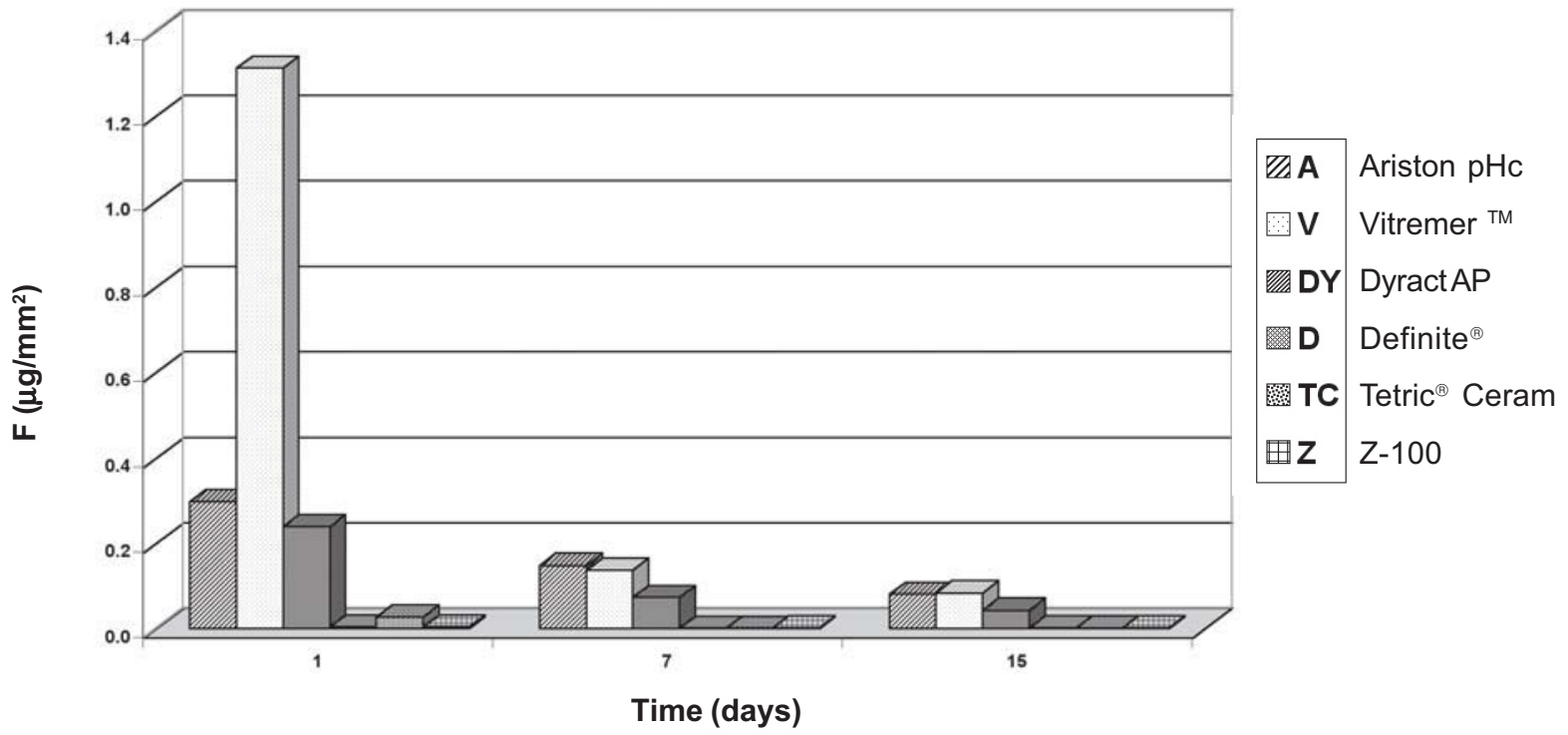

FIGURE 2- Fluoride release means $\left(\mu \mathrm{g} / \mathrm{mm}^{2}\right)$ of the restorative materials in $\mathrm{CpH}$ during 24 hours at the $1^{\text {st }}, 7^{\text {th }}$ and $15^{\text {th }}$ days

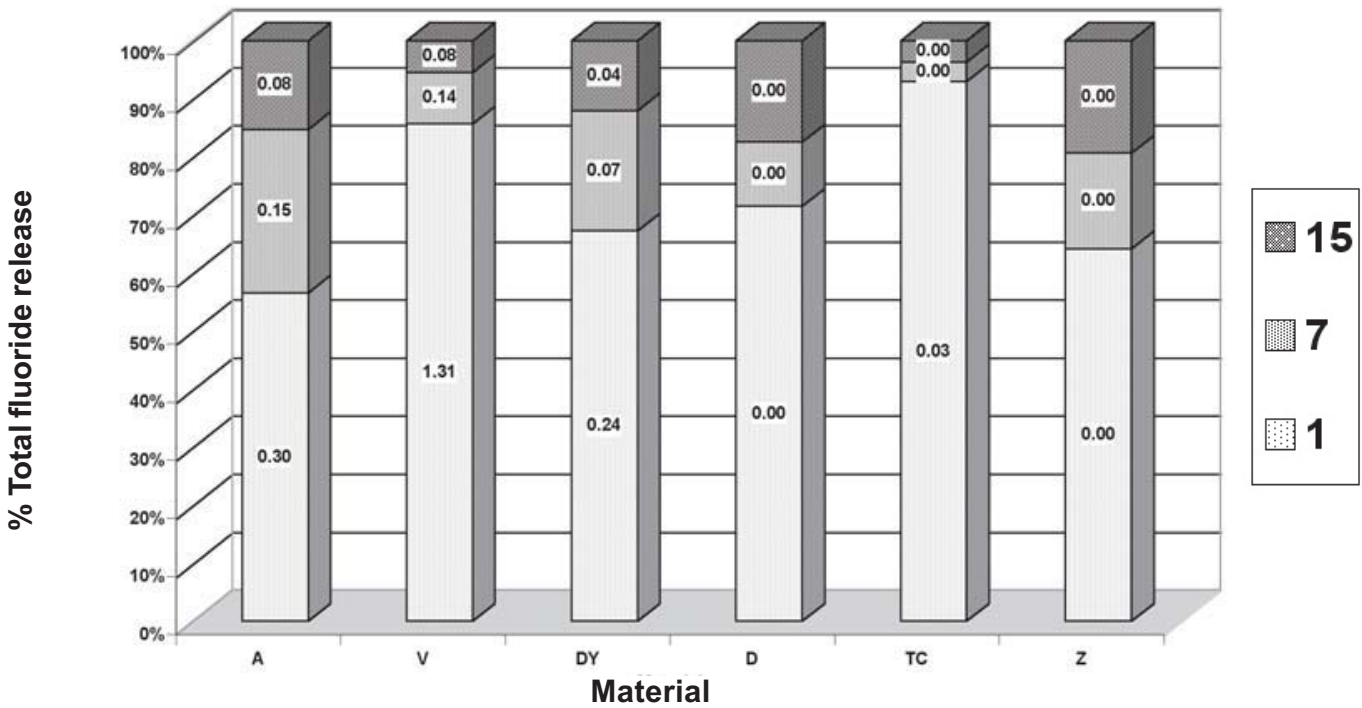

FIGURE 3- Distribution of the total fluoride release in $\mathrm{CpH}$ on the $1^{\text {st }}, 7^{\text {th }}$ and $15^{\text {th }}$ days

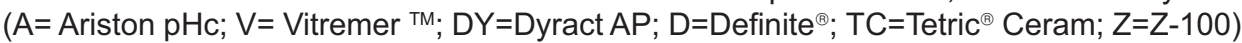


Cury $^{8}$ (1999). On the first day, the highest fluoride release was observed for all materials with a sharp decline on the second day, slowly decreasing from day 5 to day 7 , and keeping a constant level up to day 15, except for Ariston pHc, as observed by Aboush and Torabzadeh ${ }^{1}$ (1998); Grobler ${ }^{18}(1998)$; Bertacchin, et al. ${ }^{7}(1999)$; Carvalho and Cury $^{8}(1999)$.

The highest values of fluoride release were observed in the $\mathrm{pH}$-cycling (Figure 3), as compared to the deionized water medium (Table 2). In the individual analysis of each solution, there was a higher fluoride release in the demineralizing medium ( $\mathrm{pH} 4.3$ ) as also reported by Carvalho and $\operatorname{Cury}^{8}$ (1999), Geursten ${ }^{17}$ (1998) and Attin ${ }^{5}$ (1999). The resin-modified glass ionomer (Vitremer ${ }^{\mathrm{TM}}$ ) presented high fluoride release values in both immersion media, mainly on the first and second days, slowly decreasing in the following days, till the end of the experiment. Nevertheless, the polyacid-modified composite resin (Dyract), released low but constant amounts of fluoride in levels similar to those of the resin-modified glass ionomer, as observed by Shaw, et al. ${ }^{22}$ (1998). It is suggested that the fluoride release of the polyacid-modified composite resins occurs through the presence of ytterbium fluoride and glass particles, such as the alumina-silicate-fluoride ${ }^{13}$. The results obtained in this study are consistent with those of Vieira, et al. ${ }^{28}$ (1999), who tested the materials Vitremer ${ }^{\mathrm{TM}}$ and Dyract in deremineralizing cycles, simulating the acid challenge for 14 days. The highest release took place in the demineralizing solution, as compared to the remineralizing one. This release during the cariogenic challenge prevents a greater mineral loss of the enamel adjacent to the restorative materials which contain fluoride. This release occurs through two processes from dental restorative materials: a faster superficial erosion, i.e., dissolution of the material, releasing all its component parts, including fluoride, and a continuous diffusion, which can be either the release of fluoride in conjunction with an appropriate counter ion, typically sodium, or fluoride release via exchange with hydroxyl groups of the surrounding aqueous environment. According to the manufacturer, Definite ${ }^{\circledR 9}$ has $3 \%$ of modified apatite in its composition to promote the release/uptake fluoride and acid buffer. This property depends on the addition of fluoride from external sources such as dentifrice or other materials ${ }^{9,19}$. The results obtained are in agreement with those in reported the literature ${ }^{6}$. The fluoride release was lower in comparison with the values presented from the Z 100 material in both media, deionized water and the $\mathrm{pH}$ - cycling, on the $1^{\text {st }}, 7^{\text {th }}$ and $15^{\text {th }}$ days. Tetric ${ }^{\circledR}$ Ceram is a hybrid composite resin with fine filled particles and there are just a few studies on fluoride release by this material ${ }^{15,29}$. The monomer matrix is composed of Bis-GMA, urethane dimethacrylate, and triethylene glycol dimethacrylate (TEGDMA). The inorganic fillers contain barium glass, ytterbium trifluoride around 15\%, Ba-Alfluorosilicate glass, highly dispersed silicon dioxide, and spheroid mixed oxide ${ }^{1,13}$. In this study, compared to other materials, Z100 presented fluoride release, however, no statistically significant difference was found regarding Definite ${ }^{\circledR}$ and Tetric ${ }^{\circledR}$ Ceram, which contain inorganic filler with fluoride and are considered by some researchers as materials capable of releasing fluoride ${ }^{15}$ The Z100 material contains Bis-GMA, TEGDMA, $\mathrm{YbF}_{3}$ and inorganic filler of zircon and silica. This property is associated with the presence of $\mathrm{YbF}_{3}$, a radiopaque filler particle, a catalyzing substance, and less soluble than aluminum-fluorosilicate, according to the manufacturer ${ }^{15}$. The quantitative and qualitative fluoride release studies mentioned in the literature are carried out by different methods that hinder any comparisons. However, a large number of studies are carried out in vitro and therefore, do not reproduce the oral environment, even if performed in $\mathrm{pH}$-cycling ${ }^{12}$. The results of fluoride release of the esthetic materials provide evidence on the evolution of these restorative materials ${ }^{11,23,30}$. The mechanical properties of new composite resins associated with the advantages of fluoride, such as the capacity to reduce the dental plaque by means of enzymatic action, and to decrease the solubility of the enamel, might contribute clinically to the maintenance and longevity of restorations, thus, improving the oral health ${ }^{4}$. Furthermore, fluoride uptake by restorative materials would be an additional aspect in secondary caries prevention ${ }^{24}$.

\section{CONCLUSIONS}

Within the limitations of this in vitro study, it may be concluded that all materials presented the same pattern of fluoride release both in deionized water and in the $\mathrm{pH}$-cycling system. Therefore, the new formulated materials may be a new category of restorative materials acting as a permanent fluoride source, taking into account that the $\mathrm{pH}$-cycling system presented the highest fluoride release. It is important to highlight, however, that the development of fluoride restorative materials cannot be regarded as a permanent means to control dental caries lesions, but a complement along with other preventive methods.

\section{ACKNOWLEDGEMENTS}

The authors would like to thank the Biochemistry lab's technician of the Department of Physiological Sciences (FOB-USP-Brazil), Telma Lopes da Silva, and VIVADENT, Degussa, 3M Dentsply that supplied the tested materials.

\section{REFERENCES}

1- Aboush YEY, Torabzadeh H. Fluoride release from tooth colored restorative materials a 12 month report. J Can Dent Assoc. 1998;64(8):561-4, 568.

2- American Dental Association. Restorative materials containing fluoride: Council on Dental Materials, Instruments, and Equipment. J Amer Dent Assoc. 1988;116(6):762-3.

3- Araujo FB de, García-Godoy F, Cury JA, Conceição EM. Fluoride release from fluoride-containing materials. Oper Dent. 1996;21(5):185-90. 
4- Ariston pHc - Documentación científica Ariston pHc, Vivadent; 1998.

5- Attin T, Buchalla W, Siewert C, Hellwig E. Fluoride release/uptake of polyacid-modified resin composite compomers in neutral and acid buffer solutions. J Oral Rehabil. 1999;26(5):388-93.

6- Bala O, Uçtasli M, Can H, Türköz E, Can M. Fluoride release from various restorative materials. J Nihon Univ Sch Dent. 1997;39(3):123-7.

7- Bertacchini SM, Abate PF, Blank A, Baglieto MF, Macchi RL. Solubility and fluoride release in ionomers and compomers. Quintessence Int. 1999;30(3):193-7.

8- Carvalho AS, Cury JA. Fluoride release from some dental materials in different solutions. Oper Dent. 1999;24(1):14-9.

9- Definite ${ }^{\circledR}$ - Technical manual (V1). Degussa, June;1998.

10 - Dionysopoulos P, Kotsanos N, Papadogiannis Y, Konstantinidis A. Artificial secondary caries around two new F-containing restoratives. Oper Dent. 1998;23(2):81-6.

11 - Donly KJ, Grandgenett C. Dentin demineralization inhibition at restoration margins of Vitremer, Dyract and Compoglass. Amer J Dent. 1998;11(5):246-8.

12 - Eichmiller FC, Marjenhoff WA. Fluoride releasing dental restorative materials. Oper. Dent. 1998;23(5):218-28.

13 - Farah JW, Powers JM. Fluoride-releasing restorative materials. Dent Adv. 1998;15(10):2-5.

14- Featherstone JDB, Oreilly MM, Shariati M, Brubler S Enhancement of remineralization in vitro and in vivo. In: Leach, S.A. Factors relating to demineralization and remineralization of the teeth. Oxford: IRL Press;1986. p.23-34.

15- Francci C, Deaton TG, Arnold RR, Swift EJ, Perdigão J, Bawden JW. Fluoride release from restorative materials and its effects on dentin demineralization. J Dent Res. 1999;78(10):1647-54.

16- Friedl KH, Schmalz G, Hiller KA, Shams M. Resin-modified glass ionomer cements: fluoride release and influence on Streptococcus mutans growth. Eur J Oral Sci. 1997;105(1):81-5.

17- Geurtsen W. Substances released from dental resin composites and glass ionomer cements. Eur J Oral Sci. 1998;106:687-95.

18 - Grobler SR, Rossouw RJ, Van Wyk Kotze TJ. A comparison of fluoride release from various dental materials. J Dent.1998;26(3):259-65.

19- Hickel R, Dasch W, Janda R, Tyas M, Anusavice K. New direct restorative materials. Int Dent J. 1998;48(1):3-16.

20-Ismail AI. What is the effective concentration of fluoride? Community Dent Oral Epidemiol.1995;23:246-51.

21 - Rezk-Lega F, Ogaard B, Rolla G. Availability of fluoride from glass-ionomer luting cements in human saliva Scand J Dent Res. 1991;99:60-3

22 - Shaw AJ, Carrick T, McCabe JF. Fluoride release from glass ionomer and compomer materials 6-months data. J Dent. 1998;26(4):355-9.

23- Steinmetz MJ, Pruhs RJ, Brooks JC, Dhuru VB, Post AC. Rechargeability of fluoride releasing pit and fissure sealants and restorative resin composites. Amer J Dent. 1997;10(1):36-40.
24- Suljak JP, Hatibovic-Kofman SA. Fluoride release-adsorptionrelease system applied to fluoride-releasing restorative materials. Quintessence Int. 1996;27(9):635-8.

25- Taves OR. Separation of fluoride by rapid diffusion using hexamethyldisiloxane. Talanta. 1968;15:969-74

26- Ten Cate JM. In vitro studies on the effects of fluoride on de-and remineralization J Dent Res. 1990;69(Sp Issue):614-9.

27- Verbeeck RM, De Maeyer EA, Marks LA, De Moor RJ, De Witte AM, Trimpeneers LM. Fluoride release process of (resin modified) glass-ionomers cements versus (poliacid-modified) composite resins. Biomaterials. 1998;19(6):509-19.

28 - Vieira AR, de Souza IP, Modesto A. Fluoride uptake and release by composites and glass ionomers in a high caries challenge situation. Amer J Dent. 1999;12(1):14-8

29- Xu X, Burgess JO. Fluoride release and compressive strenght of fluoride releasing materials. J Dent Res. 1998;77:242.

30 - Young A, von der Fehr FR, Sonju T, Nordbo H. Fluoride release and uptake in vitro from a composite resin and two orthodontic adhesives. Acta Odont Scand. 1996;54(4):223-8. 